\title{
HispanismeS
}

Revue de la Société des Hispanistes Français

\section{Laços familiares: a palavra em espera}

Liens de famille: le mot en attente

Lazos de familia: la palabra en espera

Family Links: the Waiting Word

\section{Cleusa Rios Pinheiro Passos}

\section{OpenEdition \\ Journals}

\section{Edição electrónica}

URL: https://journals.openedition.org/hispanismes/631

DOI: 10.4000/hispanismes.631

ISSN: 2270-0765

\section{Editora}

Société des Hispanistes Français

\section{Refêrencia eletrónica}

Cleusa Rios Pinheiro Passos, « Laços familiares: a palavra em espera », HispanismeS [En ligne], 15 2020, mis en ligne le 01 juin 2020, consulté le 31 juillet 2021. URL : http://journals.openedition.org/ hispanismes/631; DOI : https://doi.org/10.4000/hispanismes.631

Este documento foi criado de forma automática no dia 31 julho 2021.

\section{(c)}

Les contenus de cette revue sont mis à disposition selon les termes de la Licence Creative Commons Attribution - Pas d'Utilisation Commerciale - Pas de Modification 4.0 International. 


\title{
Laços familiares: a palavra em espera
}

\author{
Liens de famille: le mot en attente \\ Lazos de familia: la palabra en espera \\ Family Links: the Waiting Word
}

Cleusa Rios Pinheiro Passos

\section{“Um desastre irremediável”: os relances de Clarice}

1 Em "A explicação inútil", contido em "Fundo de Gaveta"1, Clarice Lispector evoca lembranças sobre a origem ou as situações que a levaram a compor os treze textos de Laços de familia, publicado em 1960. Com sabedoria, sublinha: "Não é fácil lembrar-me de como e por que escrevi um conto ou um romance. Depois que se despegaram de mim, também eu os estranho"2. Pode-se sugerir: estranha-os porque se tornaram outro corpo, com outra configuração, a discursiva; estranha-os também porque as instâncias psíquicas (consciente- inconsciente) não se separam de modo claro e as lembranças nem sempre ressurgem no momento exigido, embora possam ser despertadas por algo inesperado a qualquer instante. Ainda assim, Clarice consegue expor sucintamente suas recordações sobre cada escrito, mas, não sobre o texto "Os laços de família", respondendo de maneira cortante a seu respeito: (dele) "não gravei nada"4.

2 Sem buscar relações entre vida e produção ficcional, é intrigante a declaração da autora, uma vez que o título "Os laços de família" quase inteiramente nomeia o livro e, de certo modo, a questão dos vínculos familiares e seus desdobramentos, amores, desejos, aprisionamentos, rupturas, pactos de silêncio, etc. se anuncia na maioria das narrativas, ou seja, tais laços constituem um dos fios fundamentais que perpassa suas tramas e personagens. A confissão de Clarice relativa a seu esquecimento é retomada porque se adequa a um importante veio do conto, que se inicia justamente por um jogo verbal, concernente ao ato de esquecer, e esse ato oculta a força dos dizeres reprimidos que operam sob o signo da repetição. Conforme se notará, o "esquecimento", presente 
desde as primeiras linhas, estará no lugar de algo reprimido que se apresenta sob a forma de repetição.

3 Significativamente, em proporções distintas, esses traços psíquicos atuam na existência de duas mulheres, mãe e filha, estendendo-se, em seguida, para sua continuidade geracional: a filha se torna mãe e seu filho adentra tal cadeia afetiva e, mais, os mesmos traços parecem contaminar, em algum momento, os elos conjugais de ambas. Há sempre uma "palavra em espera" que uma das personagens não chega a dizer ou aguarda escutar e ela não vem, não se corporifica. Logo, o apoio teórico da psicanálise e de outros campos do saber será bem-vindo, pois sustentará a leitura a ser realizada.

Em linhas gerais, "Os laços de família" trata do fim de uma visita de duas semanas de Severina à filha, Catarina, casada e com um filho de quatro anos. Ao deixar a mãe na estação de trem e retornar sozinha, a moça sente a dor e o amor maternos, relacionando-os à possível felicidade; ao chegar a seu apartamento, revê o filho, reitera e amplia as divagações anteriores e, de pronto, toma o menino pela mão e sai novamente. De passagem, apenas avisa ao marido, Antônio, sobre sua saída. Habituado a ter o sábado para si, porém com a família "em casa", ele experimenta, sozinho, sensações de perda de controle e exclusão, igualmente responsáveis por divagações a dominarem o discurso até o fim, ponto indicativo de volta à "normalidade". Se o narrador lhe cede esta segunda parte do texto, a primeira é destinada a Catarina. Tal recurso permite tanto o distanciamento do olhar narrativo para visualizar todas as cenas, conversas e movimentos de suas personagens, como as adentrar, seguindo o fluxo de consciência de cada uma, separadamente, com o intento de sublinhar suas relações, marcadas seja pelo automatismo do cotidiano - padronizado e bem sucedido economicamente - de um casal da década de 1960, seja pelo "esquecimento" da troca reveladora de seus desejos e reflexões mais íntimas. Como se vê, as poucas ações giram em torno das partidas (as de Severina e de Catarina) que acabam por desencadear afetos, inquietudes e desamparo particulares.

Recobrando o primeiro parágrafo do conto, o leitor depara com mãe e filha dentro de um táxi com destino à estação. $O$ diálogo entre elas é em aparência inócuo, porém, portador de outro sentido a merecer atenção: Severina se preocupa em contar e "recontar" as malas desnecessária e ironicamente, pois são apenas duas, perguntando pela "terceira vez" se não esquecera "nada", tendo como resposta de Catarina, algo divertida e paciente, que não. Por sua vez, em silêncio, a moça recorda da despedida entre seu marido e sua mãe, quando ambos se mostram sogra e genro exemplares, em oposição à convivência anterior em que "mal se haviam suportado" (p. 109).

6 Nessa direção, irônica e sagaz, a filha evoca as frases de Severina ao genro: "Perdoe alguma palavra mal dita" e "Quem casa um filho perde um filho, quem casa uma filha ganha mais um" (p. 110) e o desconcerto do outro que não sabe o que "fazer das malas nas mãos", nem o que dizer, pois a palavra a ser expressa, ou "em espera", é deslocada por um gaguejo e, em seguida, por uma tosse justificada pela gripe. É Catarina quem observa a vulnerabilidade de ambos, ao considerar que a segurança do companheiro se desvanece "para dar lugar a um homem moreno e miúdo", diante da "mulherzinha grisalha" (p. 110). Vale destacar: o adjetivo "miúdo" e o diminutivo "mulherzinha" apequenam os dois, torna-os frágeis e mais suscetíveis aos próprios sentimentos.

7 Logo, no momento da partida, "esquecem" as surdas disputas e o afeto negado, substituindo-os por estereótipos e ausência de palavras, ou pela des-culpa por uma palavra "mal dita". Dita mal ou maldita? A ambiguidade se instaura, já que os termos 
podem se tocar metonimicamente. Há algo de malfazejo no genro que leva a sogra a retrucar com um dito inconveniente, uma palavra dita mal? As reações das personagens não são vazias, pois, seus clichês contêm desejos inconfessos: a "velha senhora" gostaria de ter ganhado um filho "de verdade", sem a "delicadeza cautelosa" dos "bons dias e boas tardes" que trocavam. E o homem miúdo gostaria de uma sogra cujo nome não lhe fosse difícil pronunciar e não lhe provocasse culpa ao empregar um "tom de acusação e desafio" na afirmação segundo a qual o neto era "magro e nervoso" (p. 111).

"Magro e nervoso" se reiteram nas falas dessa avó que, além da desaprovação, não sabe o que dizer à filha e a repetição se instaura na pergunta constante "Não esqueci de nada?", tendo a mesma resposta, com a variação final de que esquecera as luvas com a moça. Devolvidas, a mãe entra no trem e, ainda, sem saber o que fazer, olha-se no espelho, examinando o chapéu novo, comprado no mesmo chapeleiro da moça. Aí se revela um novo deslocamento do amor não verbalizado: ironicamente, é em seu reflexo, ou seja, em sua imagem onde não está, que há um traço de identificação com Catarina, por meio de um chapéu, reiterando-se a marca do afeto em algo aparentemente externo. Parte do vestuário para proteger ou enfeitar, o chapéu oculta o não dito, pois, a mãe porta em seu corpo algo que, "sem o saber", a faz lembrar-se da filha.

9 Vale frisar que as duas mulheres "esquecem" de reconhecer o amor e as decepções mútuas. Numa passagem anterior, num instante crucial, resultado de uma "freada súbita" do táxi, uma é lançada "contra" a outra, ocorrendo "um desastre irremediável" (p. 111) - a renomada epifania de Clarice? pergunta-se o leitor -, para a mãe que balança a cabeça, tornando-se, de repente, "envelhecida e pobre", ou seja, tendo sua imagem de novo apequenada e sugestiva de uma fragilidade camuflada. Para Catarina, o "desastre" também se dá nesse corpo a corpo com Severina, "numa intimidade há muito esquecida, vinda de um tempo em que se tem pai e mãe" (p. 111).

Ora, o encontro, criado pelo acaso, desperta a "verdade" ignorada - ou parte dela - e, agora, surgida pelo toque dos corpos, não realizado de modo espontâneo e, sim, "contra", preposição que sugere oposição ou movimento contrário, insinuando não apenas a falta de intimidade, mas, sobretudo, o incômodo do contato. Além disso, essa "meia" verdade aflora, como algo peculiar ao ato de lembrar, graças ao dado "externo" que reaviva o "interno", levando a filha aos tempos de cumplicidade com o pai, quando a mãe os obrigava a comer demais e eles trocavam piscadelas coniventes. Aflora, igualmente, como nostalgia de um tempo, para sempre perdido, em que pai e mãe, mais que "laços" consanguíneos, representavam figuras que ocupavam (e, ainda, ocupam) lugares no Imaginário da filha, em sua constituição como sujeito que ganha existência, tendo acesso à linguagem, ao desejo e seus desdobramentos.

11 No encontro inesperado, revela-se, por exemplo, a falta fulcral na família de Catarina da troca de beijos e abraços, isto é, do corpo do outro. Tais carinhos acabam desviados pela mãe para a preocupação alimentar excessiva, atuante, no presente, em relação ao neto, considerado magro por ela. Comer (ingerir algo de fora para dentro do corpo) adquire outra função, a de tomar o lugar do amor que ela não conseguira demonstrar à filha, nem parece conseguir, no presente, oferecer ao neto. Não reelaborar seus sentimentos, por meio da verbalização, determina, "sem" que Severina o "saiba", o retorno do ato de outrora; repetir constitui uma forma de substituir o passado esquecido, ensina Freud 5 .

12 Assim, no táxi, o choque físico aproxima mãe e filha por um instante e, recuperadas, elas continuam sem ter o que dizer até a entrada no trem, quando Catarina observa a 
mãe e seu ar "excessivamente severo", traço já contido em seu nome ${ }^{6}$. De modo divertido, característica que a filha contrapõe a Severina, algo primordial, inconfessado por ela, vem à luz como se estivesse diante da mãe. Pensa, então: "Ninguém mais pode te amar senão eu" e, ao mesmo tempo, "não se podia dizer que amava sua mãe" (p. 112). Tais sentimentos comportam paradoxos expressivos em função do fluxo de reflexão da mulher que considera "o peso da responsabilidade" e sua consequência, dando-lhe "um gosto de sangue" à boca, "como se mãe e filha fosse vida e repugnância" (p. 112), até chegar à dura compreensão de que "a mãe lhe doía".

"Como se mãe e filha fosse vida e repugnância" ", vale sublinhar a frase, já que o narrador reúne mãe e filha, considerando-as uma coisa só, inteira, por meio da sintaxe que as converte em um só núcleo pelo emprego de uma espécie de sujeito simples, determinado pelo verbo no singular, cujos objetos, por sua vez, duplicam-se em "vida e repugnância". Em outros termos, o tranco do táxi as obriga a se tocarem, olharem e a configuração de ambas as torna um só ser - algo que fora possível apenas na gestação de Catarina - graças ao jogo da linguagem, possibilidade ímpar e fugaz de relembrar a unidade perdida?

14 A ruptura mãe-filha, provocada pelo contato físico, aponta a separação e a diferença entre elas, levando a moça a avaliar o doído amor materno. Com o trem prestes a partir, trocam olhares denunciadores de um inesperado espanto. Redescobrir o afeto "esquecido" e o afastamento, a unidade de outrora e o corte que as marca, resulta no assombro diante de algo "sabido", mas sufocado ao longo do tempo. Essa revelação só se faz na iminência da partida do trem, quando nada mais podem dizer e confissões, dúvidas e angústias são contidas. Para ocultar a falta de diálogo, proferem palavras que as identificam, num "relance" fulcral: "Mamãe" e "Catarina". Marcas fundamentais de reconhecimento, o primeiro termo (e seus diferentes sentidos, ao longo da existência) se faz fio condutor intenso na narrativa, já o segundo, "Catarina", comporta um traço sonoro sugestivo da identificação com outro nome: Severina. No eco da nomeação, ambas se refletem, assim como o fazem na maternidade. A moça tenta se afastar da mãe em sua ligação com o filho, porém restos dessa complexa convivência insistem nos novos vínculos familiares, conforme se constatará.

Antes é preciso voltar à cena da estação. Na plataforma, é a moça quem atua no desvio, graças a novo choque casual, embora mais leve. Um rapaz, ao correr, segura-a de passagem pelo braço, deslocando a gola de seu vestido, contudo, o deslocamento é outro, mais significativo e ainda a serviço da repetição, pois é Catarina quem se vê na iminência de perguntar se a mãe não esquecera de nada... Em meio a olhares atônitos, ela ainda se questiona: "Que coisa tinham esquecido de dizer uma a outra, e agora era tarde demais. Parecia-lhe que deveriam um dia ter dito assim: sou tua mãe, Catarina. E ela deveria ter respondido: e eu sou tua filha."

Contudo, passara o "relance". A ideia de "serem" mãe e filha, para além das invocações cotidianas, acaba sem a reciprocidade verbal carregada dos sentidos e laços afetivos que se perdem na recorrência desses chamados rotineiros. E, nesse instante, o encontro ainda depende da linguagem, ocorrendo no paralelismo das duas frases que elas calaram, ao longo dos anos, e que são substituídas pelo conselho banal da filha para que a mãe não pegue corrente de ar, com o acréscimo da recomendação: -"Dê lembranças a titia!” (p. 114). Tal dizer, além de guardar associações com o par esquecer-lembrar, substitui o proibido desejo de outro saber, ou seja, daquele que surge na questão cogitada, mas não proferida, sobre a felicidade de Severina ao lado do marido e, em 
seguida, a repetição das palavras anteriores - "Mamãe" e "Catarina" - reaparece, colaborando para dissimular a interdição do saber. Entretanto, essa repetição já é distinta, pois vem carregada do máximo de afeto que as personagens alcançam manifestar. Quanto a conhecer a felicidade dos pais, a curiosidade implica tanto na preocupação com a mãe, como em um (não) saber sobre sua própria concepção. Teria sido ela um ato de amor?

\section{"Só em símbolos a verdade caberia"}

Enfim, o trem parte e Catarina volta para casa, caminhando. O leitor a acompanha e se inteira de que ela estava "muito bonita nesse momento", elegante, "cabelos pintados de acaju" e, literalmente, "integrada na sua época", insinuando, "nos olhos vesgos", o gosto "pelas coisas do mundo" (p. 114). Rodeada pela "rua suja, [os] bondes velhos, cascas de laranja", a moça pressente "tudo [...] tão vivo" e "uma força" que "fluía e refluía no seu coração com pesada riqueza" (p. 114). Espiava também os passantes tentando fixar, neles, um "prazer ainda úmido de lágrimas pela mãe" (p. 115). Enfim, em meio à sujeira e à decadência dos bondes, emerge a percepção da intensidade da vida, contrária àquela sentida com Severina, quando a existência se fragiliza pela palavra esperada que não irrompe, instaurando-se o desamparo que leva Catarina a recorrer ao Imaginário das figuras paternas de sua meninice. Contudo, paradoxalmente, são os elementos "externos", da cidade, que despertam um instante "vivo e tenro", vigoroso, de prazer.

Assim, encontro e separação, relacionados à mãe, ativam um olhar diverso sobre a disposição das "coisas" a tal ponto que "o amor doloroso lhe pareceu a felicidade". E, em se tratando do olhar, cabe apontar que ele é contemplado desde o início do conto, ao se descrever o "ligeiro estrabismo" dos olhos escuros de Catarina, atributo determinante, pois comporta "um contínuo brilho de zombaria e frieza" ou "uma expressão esperta e contida" (p. 114). A isso se alia a habilidade de "rir pelos olhos", atuante desde a infância; em tal particularidade, ou seja, na do ato de desviar o sorriso para o olhar já não estaria sua própria maneira de existir, inserindo-se aí a repetição de um traço materno, o do desvio das falas e das demonstrações de afeto? Desde pequena, a personagem "rira pelos olhos" e "desde sempre fora estrábica" (p.110): as duas características escritas em seguida, tocam-se e se conectam como se formassem uma só.

Além da alteração do lugar do riso, o narrador acrescenta que, para a moça, sempre "doía um pouco ser capaz de rir" (p. 110), subvertendo-se, aparentemente, a própria função prazerosa do riso pela incorporação da dor. À primeira vista, seu intento de reprimir impressões íntimas parece impulsionar o humor a dar lugar a vestígios do sofrimento, porém, ocorre o contrário; é o humor que se coloca no lugar de tais vestígios. Na narrativa, entre várias, ele tem a função de evitar a tristeza de uma "verdade" inquietante que Catarina não pode compartilhar com seus familiares. Há, aí, igualmente, ecos do perfil materno, uma vez que a moça nada verbaliza e nada expõe pela parte do corpo destinada, convencionalmente, ao riso: a boca. Também vinculada à "fala" - que, aliás, subsiste "em espera" -, a boca é deslocada pelos olhos. Com todas as letras, a personagem "[...] nunca precisava rir de fato quando tinha vontade de rir" (p. 110).

Logo, o olhar tem duplo papel, o de rir e o de manifestar afetos e sensações ocultados por ela. Nesse jogo, entram os paradoxos de Clarice, frequentes na complexidade 
composicional de seus seres ficcionais. Se Catarina não verbaliza o que sente, por outro lado, o olhar "fala" por ela, estabelecendo uma espécie de rebeldia criativa, responsável por uma singularidade que a impele a não permanecer na mera repetição, legada pelo laço materno. Não se pode ignorar que, embora não o declare, a filha mostra bom humor, cuja presença textual acaba por desvendar certos sentimentos dissimulados pela mãe e pelo marido. E, ainda, o humor, "dom precioso e raro" ${ }^{8}$, vai além de lhe permitir fruir o prazer, apesar dos elos afetivos dolorosos, porque, no conjunto da narrativa, ele se faz recurso fundamental para sublinhar a solidão das personagens. Segundo Freud, o humor pode completar "seu curso dentro de uma única pessoa" dispensando a participação do outro. Daí, por analogia, esse curso entende-se à personagem, que usufrui sozinha determinadas situações a ponto de notar o desconcerto dos familiares na cena de despedida, ponderando: "Se eu rio, eles pensam que sou louca" (p. 110).

21 Embora o humor só se evidencie na filha, constituindo também uma das formas de defesa e suporte da própria solidão, esta atinge igualmente à mãe. Não se pode ignorar que a velha senhora viaja sozinha e, conforme se viu, é descrita por repetições e clichês - indicativos da ausência de vida interior ou da censura de seus pensamentos mais íntimos. No entanto, Catarina busca outro destino para a própria função materna. Ao chegar ao apartamento, significativamente, "enquanto se liberta[va] do chapeuzinho" (p. 115) - adereço evocativo de Severina, de quem se livra, figuradamente, por meio dele? - está disposta a "usufruir da largueza do mundo inteiro, caminho aberto pela sua mãe que lhe ardia no peito" (p. 115). Novo paradoxo aí se vislumbra; a moça procura desatar os nós maternos que a envolvem e, a um tempo, são eles que lhe sugerem outros rumos. Persiste, então, a dúvida: o ardor "no peito" se refere à dor como filha ou ao despontar do desejo de renovar sua relação com o filho?

É possível apontar essa ambiguidade, posto que o corte com a figura materna se consolida pela pergunta textual, curta e seca, do marido sobre a sogra: "Ela foi?". De maneira análoga, a mulher responde: "Foi sim" e, de pronto, empurra a porta do quarto da criança, encontra-a e experimenta um "alívio súbito". Alívio por localizar o filho onde deveria estar ou por ficar só com ele? - indaga-se o leitor. Na cena, nova epifania se desenrola. Retorna o "magro e nervoso", enunciado pela avó, na lembrança de Catarina, ao lado do reconhecimento de que o menino, sempre distraído, organiza sua fala costumeira ignorando os verbos, "não ligando as coisas entre si" (p. 115), apenas as constatando "com frieza". Porém, para o espanto da personagem, num "tom" diferente e "sem pedir nada", ele a chama: "mamãe!" (p. 116).

Distinta dos adultos que buscam ardis para não formular a palavra esperada pelo outro, aqui, a palavra vem à luz sem simulação, comovendo a moça, que se pergunta a quem deveria relatar o acontecimento e de que modo o faria. A solução seria mudar a forma $\mathrm{e}$ algumas hipóteses aparecem. Catarina contaria que a criança dissera "mamãe, quem é Deus? Ou "mamãe, menino quer Deus" (p. 116), concluindo que "Só em símbolos a verdade caberia, só em símbolos é que a receberiam." (p. 116). Reflete, ainda, "com os olhos sorrindo" que "sua mentira" se mostra necessária e "fugindo de Severina", "inesperadamente", ri "de fato para o menino não só com os olhos", mas, o "corpo todo" ri "quebrado, quebrado um invólucro e uma aspereza aparecendo como uma rouquidão." (p. 116).

A cena é plena de sugestões primordiais. Não mais ao ar livre e, sim, no espaço fechado do quarto, junto ao filho, aflora, para Catarina, o valor do Simbólico, da linguagem, da 
palavra pronunciada, reveladora de uma troca afetiva sem disfarce ou negação. 0 menino a nomeia, levado pelo desejo ("não" sabido ${ }^{10}$ ) de constatar seus elos com a mãe, num tom inexplicável textualmente, porém carregado de sentido afetivo para a mulher, que, de súbito, percebe a existência do filho pelo ato da fala e os vínculos de parentesco entre ambos se constituem, com a "verdade" possível, engendrando-se de maneira diferente daqueles estabelecidos entre ela e Severina. Aqui não há mais a "palavra em espera". A criança a enuncia. Não por acaso, em meio às conjecturas, relativas à ideia de comunicar aos demais a "mentira" sobre a invocação recebida, Catarina declara "fugir" da mãe. Imaginariamente, acredita que Severina deva estar fora de tais relações; paradoxalmente, a "velha" senhora não está. Embora negada, sua presença foi determinante para que a filha percebesse sua história, que não prescinde do passado, nem do desejo de seu lugar e função singular como mãe.

Há, ainda, as questões forjadas pela personagem, que deslocam a fala do menino. Mais uma vez, surge o deslocamento atuante ao longo da narrativa. Certa de que não poderia explicar todas as faces afetivas da evocação "mamãe", só apreendida por ela, a moça desvia tal dizer, incorporando a ele perguntas relativas a Deus. E sua escolha suscita várias leituras, uma delas pode sugerir a ideia da unidade de Deus, próxima ao sentimento de união com o filho, experimentada na gestação? Revivida, imaginariamente, nesse momento? Mais hipóteses surgem ainda: só a imagem do Absoluto daria conta de tal sensação? A criação da palavra ganharia traços divinos, daí sua contiguidade com Deus? ${ }^{11} \mathrm{Ou}$, a alusão ao Verbo não seria a forma de Catarina religar o filho com a linguagem já que, literalmente, ele "falava como se desconhecesse verbos"? ${ }^{12} \mathrm{Ou}$, ainda, a palavra reatualizaria o instante da concepção de um ser e, para tal feito, só seria compatível a presença Daquele que, na tradição judaico-cristã, criou os seres e a mãe com ele se identifica, pois, em ponto menor, ela também gera um ser, cabendo à palavra do filho marcá-lo?

Sem dúvida, a fala do menino é uma revelação inesperada e quem responde por Catarina é seu próprio corpo. O riso, "de fato", ocorre agora no lugar, sem tampouco abandonar os olhos, porque todo o corpo ri por ela. E, paradoxalmente, quebrado. Se, por um lado, cria-se a ideia negativa de fragmentação, por outro, a quebra é bem-vinda; ou seja, tal metáfora sublinha a ruptura com uma espécie de revestimento protetor que envolve seu corpo e alma (inseparáveis), levando à indagação: do que se protege a personagem? E para quê? Ao longo do texto, observa-se, pelas reflexões do marido, seu papel como esposa de "engenheiro" bem-sucedido: tranquila, calada, sempre atenta ao "apartamento arrumado, onde 'tudo corria bem", para que o companheiro, "cheio de futuro", obtivesse mais sucesso econômico-social. Surda (?) e ironicamente, ela o ajudaria a conseguir "e odiaria o que conseguissem". (p.118).

27 Assim, as imposições sociais não questionadas dessa típica esposa burguesa dos anos 1960, no Brasil urbano, aliam-se a certa transmissão dos traços paternos. Severina parece ter sempre lhe negado a "palavra esperada" sobre o amor, as relações conjugais e a existência; já seu pai surge em uma só passagem como cúmplice da dissimulação diante da mãe, sugerindo quase uma ausência de voz. Assim, o dado social, a influência da rede familiar e o casamento padronizado criam o "invólucro" que parece inibir Catarina de seguir um caminho próprio. Vale destacar que o movimento feminista, no Brasil, se fez muito gradativamente, basta observar que apenas em 1932 é garantido o sufrágio feminino. E, mais espantoso, só na Constituição de 1988, no que concerne ao 
Direito de Família, o homem deixou de ser "o chefe da sociedade conjugal", podendo ambos exercer "direitos e deveres [...] de igual forma".

"Os laços de família", reiteramos, foi publicado em 1960. E entre essa década e a de 70, eclode a "revolução sexual", mas, muito da educação conservadora de séculos persiste, refletindo-se tal dado na personagem que representa anos anteriores e um pouco dos vindouros, sem menções temporais claras. Um exemplo se encontra em sua submissão ao pudor exigido à grande parte das mulheres, ao se incomodar em ser vista nua pelo parceiro, atitude aceita entre quatro paredes e no escuro, isto é, o recato impede o abandono do corpo ao olhar do marido ${ }^{13}$. E, no conto, é ele quem o relata, confessando entrar no quarto, enquanto Catarina troca de roupa, intentando humilhá-la, sem saber por que o faz. Uma resposta estaria no desejo de manter o poder sobre ela, estendendo a dominação econômica ao que a companheira tem de mais íntimo e exclusivo, seu corpo, marcado por imposições da moral e da educação tradicionais.

Dessa perspectiva, a fragmentação metafórica, suscitada pelo filho, mostra-se benéfica porque permite a Catarina, embora sugestiva e momentaneamente (mas, em Clarice, o relance é sempre crucial!), livrar-se das amarras sociais, suspender, em parte, os deslocamentos que a regem - o riso volta a seu lugar -, reconhecer-se como sujeito de seu desejo e aceitar sua divisão psíquica (consciente/inconsciente), sua origem e continuidade; em suma, acolher a própria história e a busca singular de seu destino: a moça tem muito da mãe, mas se constitui outra pela e na relação com o filho e é graças a ele que poderá mudar. Quanto às relações com o marido, nada se explicita a esse respeito; todavia, a saída com a criança, sem justificações, parece desafiadora, já que desencadeará ruptura (instantânea ou duradoura?) da composição do casal e inquietude no parceiro.

Voltando ao trecho decisivo para Catarina, surge-lhe também uma "aspereza" semelhante a uma rouquidão, uma repentina alteração no tom de voz, denunciadora da mudança de seu olhar. O motivo não seria problemas nas cordas vogais, mas nova reação do corpo à voz afetiva e desinteressada da criança que demanda a reciprocidade amorosa da mãe. A surpresa e o hábito de se calar, ocultando seus quereres, geram o uso indevido da voz (como a gagueira e a tosse ligeiras do marido ante a sogra?), e a resposta esperada pelo filho não vem, tanto que, em seu Imaginário, ele reage, com uma espécie de desacato infantil, chamando-a de "feia", e, ela, evita, uma vez ainda, o enfrentamento do afeto a retribuir. Sua resposta se dá pelo rubor e pelo ato que substitui a "palavra esperada" (e bem-dita), a saber, o convite desviante: "Vamos passear" (p. 116).

31 A saída é brusca, e a passagem pela sala não dá tempo ao marido de nada perguntar. Bate a porta e parece estabelecer com o menino um elo em que o pai não tem lugar. Não se pode ignorar que uma mãe, desde o princípio, propicia ao filho a existência, é fundamental a sua sobrevivência enquanto recém-nascido, aos cuidados com o corpo que o marcam como ser e à introdução à linguagem, ao Simbólico, portanto, o que lhe permite acesso ao desejo. Nessa direção, Catarina dá continuidade a algo, há muito vivido, para redescobrir "a verdade" que "só em símbolos [...] caberia" agora e que lhe foi sinalizada pela palavra do menino.

32 No entanto, não se pode apagar, queira ela ou não, o legado de Severina. Os laços de família não se esvaem por inteiro, impõem-se como traços. Logo, a moça não escapará da parte incômoda de tal herança sem reconhecer as repetições e as transformar em lembranças. Sutilmente, ela começa a elaborar tal processo no momento em que 
retornam os episódios da comida excessiva, imposta por sua mãe, e da falta de abraços e beijos dos pais ao longo dos anos, importantes aspectos para alguma compreensão da insistência atual das repetições e da negação dos afetos. 0 jogo das recordações aparece, igualmente sutil, no arranjo textual, organizado por flashbacks, que intercalam presente e passado: enquanto olha seu entorno, Catarina relembra de pequenos eventos de outrora (as já referidas cenas da meninice) ou de acontecimentos recentes (a despedida entre Severina e Antônio, por exemplo.)

Esses laços paradoxais nem sempre incluem o marido. De maneira expressiva, também o pai da personagem, aparentemente, não fez parte de várias relações entre mãe e filha. Determinadas exclusões, consideradas costumeiras para uma das figuras parentais, implicam consequências dolorosas no conto. O leitor se interroga: o que significaria para a vida adulta de Catarina certa exclusão do pai? o que não lhe foi transmitido no núcleo familiar estabelecido de sua infância até a formação de seu próprio núcleo com Antônio? O que foi e se esvaiu? O que se repete do modelo dos pais que ela e o marido incorporam e alteram por certos fatores socioeconômicos da modernidade? E qual o peso das normas sociais nos jogos conjugais dos dois casais?

Textualmente, não parece haver a comunicação necessária entre a personagem e o marido, assim como não havia entre ela e seus pais. Por não saber o modo pelo qual os laços dos pais se constituíram, a moça repete o padrão? Ou o conforto socioeconômico evita qualquer palavra incômoda? Ou ambos? O fato é que a palavra do filho, uma espécie de "eu existo" fundamental, acorda Catarina para sua implicação na função materna, sem que o conto o exponha literalmente. Esse despertar gera reações, ao atingir Antônio. De maneira análoga, este começa a perceber seu papel como pai e marido; algo que lhe é doloroso e cruel.

\section{"O mistério partilhado"}

A construção ficcional de Clarice aí se mostra primorosa. Se no que se pode denominar primeira parte, conduzida pela perspectiva da personagem feminina, havia traços de identificação da filha com a mãe e, da mesma forma, alguma negação por parte de Catarina; na segunda, concentrada na personagem masculina, esboçam-se aspectos do processo de projeção, ou seja, imaginariamente, Antônio "vê" no filho aquilo que não admite em si, configurando-se tal procedimento, de modo paradoxal, também uma negação, conforme se perceberá. Não por acaso, essa sub-reptícia "partilha" do conto em dois momentos, cada um voltado para uma personagem, insinua a solidão e certa incomunicabilidade do casal.

Logo, tais momentos constituem paralelismos exemplares, como se um pudesse espelhar o outro, graças a recursos ficcionais semelhantes; no entanto, o casal se reflete em pontos mais ligados às circunstâncias sociais e o texto não registra nenhuma comunicação sobre seus desejos, angústias, recordações etc. Catarina e Antônio acabam se desvelando apenas por meio do fio narrativo que lhes dá ampla liberdade de lembrar, desejar, amar, rejeitar, negar, projetar e, sobretudo, imaginar. E é o Imaginário do marido que elabora o segundo momento da trama.

37 Vale, então, retomar a cena da partida da mulher, quando o olhar de Antônio passa a atuar. Já foi destacado que o olhar desviante, "malicioso" e capaz de transbordar o riso da moça, transmite certo bom humor, operando uma espécie de mecanismo de defesa. Bem diferente é o de seu companheiro, cujo olhar angustiante e deformador sugere 
aplanar, diminuir o outro, igualmente numa defesa ante o que lhe escapa. Basta observar a passagem fulcral em que, da janela do apartamento, Antônio enxerga, "aborrecido", Catarina e o filho na calçada, concebendo literalmente a companheira como "forte", "prendendo com força a mão da criança [...] com olhos fixos adiante; e mesmo sem ver, o homem adivinhava" (p. 117) a boca da mulher "endurecida. A criança [...] também olhava fixa para frente, surpreendida e ingênua" (p. 117). Especular à mãe? Ora, é seu olhar que está fixo nas duas figuras, quanto ao delas, ele só pode "adivinhar" a mobilidade, o endurecimento ou a surpresa, de acordo com suas próprias fantasias. $\mathrm{E}$ o mais inquietante é que, vistas de cima, ambas perdem "a perspectiva familiar", parecendo-lhe "achatadas ao solo e mais escuras à luz do mar" (p. 117).

"Forte", "com força" e submetida ao verbo "adivinhar", que insinua algo a antever, conhecer ou intuir por indícios, propiciando o surgimento de efeitos imaginários na construção do cenário avistado por Antônio, Catarina ganha uma potência ameaçadora. A possibilidade de sua mulher constituir-se sujeito desejante o assusta? Seu mero movimento de andar para frente o atemoriza, pois, habituado ao ritual de uma família paralisada, sem oferecer nenhum risco, enquanto "ele tomava o seu sábado" (p. 117) sugestivo do ato de se apoderar de todos os sábados e, ilusoriamente, da mulher e filho -, ver-se perante a nova situação, provoca um desequilíbrio e faz irromper a sensação inesperada de estranheza, vinculada à angústia: os dois seres familiares se deformam, ensombrecendo-se e sendo despojados das características conhecidas por meio do olhar conflitante de um pai, que se percebe excluído dos vínculos estabelecidos entre mãe e filho, ignorando que ele próprio se excluíra, quando escolhera um modo de convivência, de acordo com seu prazer, sem intromissões.

O estranhamento - tão constante na obra de Clarice - atinge Antônio com intensidade. "Preocupado", ele vê a mulher conduzir a criança, "fora de seu alcance", aflorando uma espécie de quebra de sentido de sua vida organizada, sem fissuras ou transformações e a solidão - embora de algumas horas (de algumas horas ou da existência, até agora ignorada?) - desencadeia o sentimento de desamparo. Surge, então, o temor de que Catarina, ao guiar a criança, literalmente, "transmitisse a seu filho... mas o quê?" (p. 117) se pergunta ele. $O$ discurso é interrompido e as reticências sugerem uma palavra suspensa ou "em espera", pois ligada a algo angustiante, não enunciado ao longo da vida.

Por outro lado, diante dessa cena, a angústia, "aquilo que não engana", segundo Lacan $^{14}$, e não engana porque é um sinal a Antônio de seu temor de desaparecimento, revelando que sua existência, construída nos moldes do "sucesso" social, corre o risco de se esvair. Sua reação o leva, assim, a dirigir um apelo paradoxal (um grito sufocado) à mulher, como se ela pudesse ouvi-lo: "Catarina esta criança ainda é inocente!" (p. 117). O homem revive, imaginariamente, a própria perda da inocência no outro, no menino que constitui sua continuidade. A angústia age, ainda, na elaboração doída de uma dúvida ligada à "prisão de amor", dada pela mãe à criança (que ele deve ter sido), que "se abateria para sempre sobre o futuro homem" (p. 117).

41 Os traços projetivos tornam-se aí evidentes: o Imaginário de Antônio dispõe o menino, no futuro, e no mesmo apartamento no qual ele está no presente, atrás da vidraça, por onde vê duplamente a si próprio, graças a seu reflexo, e às figuras familiares ao longe. Confundem-se as imagens. Distanciando-se delas, Antônio se visualiza no espelho e no filho e é seu discurso que reflete tal duplicidade ao capturar a ambos - pai e filho - em terceira pessoa, como se fossem figuras alheias: 
[...] Mais tarde seu filho, já homem, sozinho, estaria de pé diante desta mesma janela, batendo dedos nesta mesma vidraça: preso. Obrigado a responder a um morto. Quem saberia jamais em que momento a mãe transferia ao filho a herança. $\mathrm{E}$ com que sombrio prazer. Agora mãe e filho compreendendo-se dentro do mistério partilhado. Depois ninguém saberia de que negras raízes se alimenta a liberdade de um homem[...]. (p. 117-118)

as fantasias de Antônio, que parece crer estar respondendo a seu próprio pai, sem o mencionar. E, ainda, ele destaca a força do peso da herança materna, contudo, ao aludir ao "pai morto" sublinha o traço que também lhe pesa e que não tem lugar em seu discurso, a não ser quando projetado no filho em forma de inquietante devaneio. Haveria aí uma radical "palavra em espera", pois não dita diretamente ao pai. Nesse aspecto, a repetição também atua em suas relações familiares, o que não foi resolvido, em certas etapas da vida, retorna de forma inquietante em outras. Há, talvez, semelhança entre os elos de Catarina e Antônio com seus pais. O leitor nota tanto a opressão dos laços consanguíneos como a dos laços afetivos (sociais), ilusoriamente seguros, formados no decorrer do tempo. Embora de maneira diversa, o silêncio já despontara na relação entre Catarina e sua mãe; só que a moça não se limita a receber sua herança e transmiti-la ao filho. Ao escutar - e o grifo aqui é importante - a palavra esperada ("mamãe"), Catarina percebe sua função, compreendendo que deve construíla, indo além do legado materno, sem o negar inteiramente, mas traçando percursos e marcas singulares.

Já Antônio se mantém paralisado em seu desamparo: "Mas e eu, eu?" pergunta-se assustado. Mulher e filho "tinham ido embora sozinhos. E ele ficara. 'Com seu sábado", sublinhado com aspas pelo narrador. "E sua gripe. No apartamento arrumado onde 'tudo corria bem"'. De novo, pelas aspas, o narrador reforça o alerta ao leitor: a tranquilidade descrita oculta algo prestes a explodir. Quem sabe, reflete Antônio, sua mulher não estaria fugindo "da sala de luz bem regulada", frase que camufla a não formulada por ele, a da fuga de um cotidiano automatizado, no qual as vozes são sufocadas, tanto que, até quando ele a humilha, é com "ternura", como se fosse possível conciliar os dois tratamentos. Na solidão, o homem percebe que, das relações "pacíficas" do casal, criava-se a "atmosfera do lar" para o filho. Todavia, é esse mesmo filho que, às vezes, se irritava e, sobretudo, "gritava sob pesadelos" (p. 119), ou seja, em seus sonhos manifestava-se a angústia. E o pai se questiona: "De onde nascera esta criaturinha vibrante, senão do que sua mulher e ele haviam cortado da vida diária". (p. 119). E o que cortaram? Melhor seria perguntar: o que esconderam? Além dos desejos e angústias que não confessam, a alegria que Antônio imagina a mulher estar vivendo sozinha com o filho.

No entanto, toda a descoberta de Antônio frente a seu desamparo parece não ter consequências quanto a seu modo de vida. Novo deslocamento se propõe no desenlace 
do conto: a luz da tarde recai "com gravidade sobre os objetos" (p. 119) do apartamento, porém não mais sobre a maneira de encarar seu papel frente aos vínculos paterno e conjugal. Ele espera a volta de Catarina para jantar, afastar as mariposas, escutar o grito do menino no primeiro sono, o som incessante do elevador e resolve, sem a consultar, que iriam ao cinema e, depois disso, o "dia se quebraria com as ondas" (p.120) como sempre. Enfim, retorna o automatismo do cotidiano para calar qualquer conflito. A questão é: até quando? Já com Catarina, não se pode afirmar o mesmo, pois, a cena, que revelou uma impossibilidade de ela formular a palavra de amor esperada pelo filho, tem também outra face: a do gesto inaugural de, inesperadamente, tomar o filho pela mão - corpo a corpo, sem "desastre" - e com ele sair em busca de mais um paradoxo, o "mistério partilhado". Se o pequeno e rasteiro devaneio do marido encena a repetição do mundo, não se pode saber como será o da mulher. E como o leitor não tem mais acesso a ela, resta-lhe também partilhar o mistério, sem jamais o descobrir.

\section{"Um destino de mulher": "o fio partido..."} citadas, por exemplo, o olhar substituindo a palavra, a solidão, as relações tanto conjugais como entre pais e filhos, o desejo, a angústia, as recordações, etc. Todas vão ganhando espaço na escrita insubordinada de Clarice que joga com desvios da linguagem para demarcar e desarranjar um mundo estereotipado, rearticulando-o pelo ato criativo. Nessa trilha, um aspecto se torna mais relevante para a leitura proposta, ou seja, a questão da palavra em espera, do temor de pronunciá-la ou de seu deslocamento por uma cena e/ou frase que dissimula os desejos das personagens, particularmente, as femininas, porque evocam Catarina, ou Catarina as evoca (embora algumas masculinas também se elaborem por processo semelhante; basta citar Antônio ou o narrador de "O jantar" que, calados, projetam em outros seres, graças ao olhar, seus ressentimentos e angústias).

Assim, sucintamente e sem obedecer à cronologia do livro, serão retomados os textos "A imitação da rosa", "Feliz aniversário" e "Amor"15, pois, neles, a repetição, o olhar agudo, a dor de (não?) "cair em um destino de mulher" (p. 18), a asfixia do desejo, a palavra "não dita" e um elemento disruptivo atingem suas personagens, aproximandoas, em maior ou menor grau, de Catarina. Em linhas gerais, Laura, figura central de "A imitação da rosa", volta para casa ou "à insignificância com reconhecimento" (p. 36) da dona de casa, vale acrescentar? -, saída de alguma clínica e disposta a retomar o cotidiano anterior, que, por ironia, combina com as recomendações médicas a observar: o método tranquilo da mesmice, da imobilidade e do esquecimento. 0 narrador, em terceira pessoa, segue o fluxo de pensamento da mulher e entre suas lembranças ressurgem, nos olhos, "o ponto ofendido" de uma falta "de filhos" (p. 36) ou o gosto 
pelo método, ao lado da obrigação de controlar a ansiedade, conforme ordens terapêuticas, para voltar à "normalidade".

o conto é exemplar em termos do paradoxo entre a lucidez luminosa e o automatismo de repetição destruidor, este considerado não só um traço (sintomático?) da personagem, mas, sobretudo, uma proposta médica para atenuar sua ansiedade e retornar à insipidez do cotidiano. Horário do leite, dos remédios, esquecimento dos conflitos e "do que aconteceu", em uma palavra, repressão da angústia, evitando contaminar a quietude alheia, no caso, a do marido. E, por outro lado, o conselho de abandonar-se... Ora, nada se enuncia claramente no conto. O leitor não sabe se Laura esteve em uma clínica psiquiátrica, o que lhe ocorreu ou que a levou à suposta internação, tudo é insinuado, as palavras precisas ficam em espera.

Contudo, entra o elemento disruptivo: a personagem compra rosas silvestres, "miúdas", perfeitas, que a encantam e iluminam sua sala a ponto de a beleza e a perfeição incomodarem profundamente e ela pensa em presenteá-las à amiga e, no fim, o fará, mas o risco da beleza já se instaurara, assim como o devaneio prazeroso da maneira pela qual as flores seriam recebidas, opondo-se à hesitação maior de realizar seu desejo, ficando com as rosas. Há aí uma quebra da rotina e o conflito se estabelece: ter ou não as flores? Parece pequeno, mas é um conflito e Laura ainda se impõe outro: "a uma coisa bonita falta [va] o gesto de dar", mas, para preencher essa falta específica, será necessário abdicar da realização do desejo. 0 perigoso círculo da repetição se inaugura em outro nível, não mais envolvendo aspectos da repetição embrutecedora do cotidiano da casa, e, sim, a repetição movida pelo desejo que é despertado pela beleza, encadeando os elos da perfeição, do prazer de olhar, gerando o ato de se perder na dúvida entre o ter e o doar.

Quando o marido volta do trabalho, Laura não está pronta para sair, no entanto, mostra-se serena e "desabrochada". Como as rosas. Ela só consegue dizer que não pode impedir... o quê? Não se sabe. E, aqui, impossível não lembrar do impasse verbal semelhante ao de Antônio em "Os laços de família". O objeto direto faltante constitui a palavra em espera e a cena final desloca a possibilidade de que tal palavra viesse a ter lugar. Laura permanece no sofá com sua metáfora paradoxal, única a dar conta do que não se apreende: "alerta e tranquila como um trem. Que já partira" (p. 58). Nova suspensão verbal ocorre e resta a dúvida: impossível de ser refreada, a personagem partira para onde? Domina o que costumeiramente se designa por "loucura"? perguntase o leitor? Ou domina o que chamaríamos de "outra lógica", ou seja, a lucidez de viver seu desejo sem as amarras do princípio de realidade? Clarice nos impulsiona a decidir: qual a pior repetição, a do automatismo engendrado pelos costumes sociais das reiterativas tarefas cotidianas de qualquer trabalhador, sem o prazer específico do "método" como queria Laura, ou a do desejo singular que pressupõe sonhos e devaneios, ainda que distantes do princípio de realidade?

Por sua vez, em "Feliz aniversário", a repetição adentra a maneira pela qual as personagens do conto chegam à festa de D. Anita, a mãe, avó e sogra que completa 89 anos. Todos os convidados teatralizam seus movimentos, pois cumprem um papel que não lhes agrada. As relações consanguíneas são substituídas pelas socioeconômicas, a família se divide em classes diferentes e determinadas pelos bairros do Rio de Janeiro de onde provêm e, ainda, por mero costume da cultura ocidental, cabe a Zilda, a única filha mulher a cuidar da mãe. É ela, então, a primeira a abafar o discurso que gostaria de enunciar por sua irritação devido às tarefas gerais, sem a contribuição dos demais. A 
fala contida se desloca para seu "coração revoltado" (p.64). Além disso, Zilda teme a fala alheia, ligada à reprovação dos parentes, diante de D. Anita que cospe no chão, envergonhando-a. Nesse momento, há uma inversão de papéis, e a filha acredita ter por função educar a mãe.

A cuspida configura-se o resultado da "cólera" da velha senhora, depois da reflexão não enunciada, porém, metaforicamente, expelida do corpo pela boca, mesmo lugar da fala reprimida. A aniversariante acaba de repensar a vida e a geração de filhos, netos e bisnetos, avaliando sua época, seus valores e os da família, sentindo "desprezo pela vida que falhava" (p. 66) e se espantando que um "tronco" bom, como fora o seu, desses frutos "azedos e infelizes", sem capacidade de uma "boa alegria". Em seguida, ainda considerando a família como "ratos se acotovelando" e sufocada pela raiva, D. Anita suspende a palavra precisa e a substitui pelo chocante pedido de um "copo de vinho". Significativamente, ela não o bebe, pois está no lugar de outro desejo e sua função é abalar os presentes.

Nessa narrativa, "a verdade" (ou parte dela) é de tal forma deslocada, que só a encontramos em Cordélia, a nora mais moça e, sobretudo, calada. Ela vai percebendo a festa e se manifestando pelo olhar: sorrindo, esbaforida, ausente, espantada, estarrecida; até a cena disruptiva na qual se dá conta "num ímpeto dilacerante" do dizer mudo da sogra: "É preciso que se saiba. É preciso que se saiba. Que a vida é curta. Que a vida é curta" (p. 71). o narrador recupera o clichê e o rearticula, quebrando a sintaxe e obrigando o leitor a reelaborar duas vezes a oração para lhe dar sentido. E isso é um relance. Só assim se obtém a verdade.

Os dois contos, cada um a seu modo, compõem a repetição, elemento importante em "Os laços de família", e, como Catarina, a figuras de Laura, Zilda, D. Anita ou Cordélia não conseguem exprimir pelo verbo o que sentem, substituindo-o por um discurso desviante e "inútil", reprimindo seus desejos. Funciona a força do olhar, que substitui igualmente a palavra suspensa: em Laura, ele se manifesta, desejante, diante das rosas; em Cordélia, sempre com atributos graduais de estranhamento diante da indiferença de todos perante a velhice e a brevidade da vida. Em todas, a solidão.

Por fim, Ana, de "Amor", também não escapa de tais armadilhas e cai "num destino de mulher, com a surpresa de nele caber como se o tivesse inventado", pois, bem casada, dedicada a marido e filhos, esquece "seu desejo vagamente artístico" para lembrar dele apenas quando, de um bonde parado, observa um cego mascando chiclete e seu contínuo movimento de parecer "sorrir e deixar de sorrir" (p. 20). De repente, o bonde arranca e seu saco de compras cai, assustando-a. Estamos diante de uma repetição muito próxima a de Catarina, só que, agora, ela se dá na imagem do cego, aquele que não vê, mas faz Ana ver, e a arrancada do bonde substitui o "desastre irremediável" do táxi da outra personagem. Estendendo-se a imagem, o bonde é deslocado pelas rosas em Laura e pela velhice que ultrapassa o ser em Cordélia.

São momentos desencadeadores de mudanças. Cada mulher reage de uma forma e Ana vai para o Jardim Botânico e depara com um universo inesperado. Se todas tentavam apaziguar a vida, conforme se lê em "Amor", para que "esta não explodisse", sem dúvida, a vida explode. $\mathrm{E}$, em todas, a palavra sobre o futuro resta suspensa. Com Ana, a "flama do dia" se apaga como uma vela; o marido de Catarina a espera, mas não se vê seu retorno e as ondas continuam a se quebrar...; Laura parte "como um trem". Sem retorno? Cordélia se deixa levar pela mão do filho... Para onde? Não se pode ignorar que os contos se constroem em terceira pessoa e o paralelismo dos desenlaces de Catarina e 
Ana, por exemplo, não significa que elas voltem a seus cotidianos como antes. Para Ana, fica a pergunta: “O que o cego desencadeara caberia nos seus dias?" (p. 29). Para Catarina: quebrado o invólucro e partilhado o mistério entre ela e o filho, bastariam o jantar e o cinema habituais para apagar a revelação do dia? Textualmente, sua voz e pensamento não têm mais lugar e tal suspensão ganha o papel fundamental de preservar a dúvida no leitor. A incerteza toca, de modo semelhante, o destino de todas. No entanto, não se pode ignorar o encontro de tais personagens com alguma verdade de si mesmas, verdade singular, instantânea, nunca toda, mas fundamental para se constituir como barreira ao esquecimento do próprio desejo. Logo, Clarice acerta ao elaborar relances da "verdade" de formas distintas e surpreendentemente reveladoras.

\section{BIBLIOGRAFIA}

Nádia Batella Gotlib, “Os difíceis laços de família”, Cadernos de Pesquisa Fundação Carlos Chagas, n. 91 (nov. 1994), p. 93-99.

Mary DEL PRIORE, Histórias íntimas: sexualidade e erotismo na história do Brasil, São Paulo, Editora Planeta, 2011.

Sigmund FREUD, "Recordar, repetir e elaborar", Observações psicanalíticas sobre um caso de paranoia relatado em autobiografia ("O caso Schreber"), Artigos sobre técnica e outros textos (1911-1913), São Paulo, Companhia das Letras, 2010, p. 193-209.

Sigmund FREUD, "O humor" (1927), Inibição, sintoma e angústia, O futuro de uma ilusão e outros textos (1926-1929), São Paulo, Companhia das Letras, 2014, p. 322-330.

Sigmund FREUD, "Os chistes e sua relação com o inconsciente" (1905), Obras completas, Rio de Janeiro, vol. VIII, Imago, 2015, p. 1-155.

Jacques LACAN, Le séminaire livre X, L'angoisse, Paris, Éditions du Seuil, 2004.

Clarice LISPECTOR, A legião estrangeira, Rio de Janeiro, Editora do Autor, 1964.

Clarice LISPECTOR, Laços de família, 10ª . ed., Rio de Janeiro, José Olympio, 1978.

\section{NOTAS}

1. Clarice LISPECTOR, A legião estrangeira, Rio de Janeiro, Editora do Autor, 1964.

2. Ibid., "Fundo de gaveta", p. 172.

3. Clarice LISPECTOR, Laços de família, 10ª ed., Rio de Janeiro, José Olympio, 1978, p. 109-120. A partir de agora, as citações desta obra serão identificadas apenas com o número da página no próprio texto.

4. Clarice LISPECTOR, "Fundo de gaveta", A legião estrangeira, p. 174.

5. Sigmund FREUD, "Recordar, repetir e elaborar", Observações psicanalíticas sobre um caso de paranoia relatado em autobiografia ("O caso Schreber"). Artigos sobre técnica e outros textos (1911-1913), São Paulo, Companhia das Letras, 2010, p. 201. 
6. Feminino de Severino, do latim Severinu der. de Severo.

7. Grifo meu. Cabe esclarecer que a frase está no singular em quatro edições da obra, ou seja, não parece haver

erro na publicação e, sim, constituir a própria escrita da autora, o que permite a interpretação aqui sugerida.

8. Sigmund FREUD, "O humor"(1927), Inibição, sintoma e angústia, o futuro de uma ilusão e outros textos (1926-1929), São Paulo, Companhia das Letras, 2014, p. 330.

9. Sigmund FREUD, "Os chistes e sua relação com o inconsciente" (1905), Obras completas, Rio de Janeiro,

vol. VIII, Imago, 2015, p. 150.

10. Há sempre algo que pensamos não saber, pois quem "sabe" é o Outro, o Inconsciente, que tem lógica própria e "pensamentos", "sabendo" o que acreditamos ignorar. Contudo, esse "algo ignorado" pode aflorar a qualquer instante no que a psicanálise nomeia "formações do inconsciente", ou seja, nos sonhos, lapsos, atos falhos etc. ou na fala inesperada do semelhante. No conto, é o chamado do menino o responsável pela produção do choque na mãe, que, repentinamente, captura o novo sentido de sua função materna.

11. Não se pode esquecer a afirmação bíblica:

No princípio era o Verbo e o Verbo estava junto de Deus, e o Verbo era Deus.

Ele estava no princípio junto de Deus. Biblia Sagrada. Prólogo.

Tudo foi feito por ele; e nada do que tem sido feito, foi feito sem ele.

Nele estava a vida, e a vida era a luz dos homens."

“(Biblia Sagrada. Prólogo: João 1:1-4)

12. Agradeço a Suely Corvacho tal observação.

13. Cf. sobre o assunto: Mary DEL PRIORE, Histórias íntimas: sexualidade e erotismo na história do Brasil, São Paulo, Editora Planeta, 2011, p. 177.

14. Jacques LACAN, Le séminaire livre X, L'angoisse, Paris, Éditions du Seuil, 2004, p. 85-97.

15. Os três contos aqui mencionados compõem a mesma edição de Laços de família, já citada no início. Cabe também esclarecer que, sob outra perspectiva, “Amor" e "Feliz aniversário" já foram relacionados a "Os laços de família" por Nádia Batella Gotlib, "Os difíceis laços de família", Cadernos de Pesquisa Fundação Carlos Chagas, nº 91 (nov. 1994), p. 93-99.

\section{RESUMOS}

La lecture de la nouvelle de Clarice Lispector «Les liens de famille », proposée ici, se concentre sur la parole maintenue en suspens qui caractérise la vie d'un couple. Malgré leur réussite sociale et économique, ils se taisent sur leurs désirs et leurs angoisses ou sur leurs relations affectives. Seuls le regard et le courant de conscience de chaque personnage donneront accès, au lecteur, à leurs sentiments de manière isolée. Les personnages semblent répéter et, en même temps, nier les traits hérités de leurs parents, entre autres, le silence sur leurs sentiments. Dans ce sens, ils attendent toujours la parole de l'autre qui ne se manifeste pas. Lorsqu'il invoque de manière inattendue sa mère, le fils brise la chaîne et déclenche des mouvements inquiétants dans la vie du couple.

The analysis that ensues of "Os laços de família" focuses on the unsaid words that underlies the life of a socially and economically successful couple who is not so much so in their affective 
relationship as they keep silent about their desires and anxieties. The reader will only have access to this lack of communication through each other's gazes and stream of consciousness separately. The characters seem to repeat and, at the same time, deny to each other, their traits inherited from their parents concerning their silence about their affection. This way they keep imagining the word that was not externalized by the other. The one that interrupts this chain is the little son when he unexpectedly calls on his mother, which gives rises to disturbing movements in the couple's existence.

\section{ÍNDICE}

Mots-clés: Laços de família, Os laços de família, relations familiales, solitude, répétition, parole en attente, imaginaire

Keywords: Laços de família, Os laços de família, family relationships, loneliness, repetition, the unspoken, imaginary

\section{AUTOR}

\section{CLEUSA RIOS PINHEIRO PASSOS}

Université de São Paulo 